\title{
Stability of Vitamin C in Broccoli at Different Storage Conditions
}

\author{
Nasser Al-Habsi ${ }^{\mathrm{a}}$, Sithara Suresh ${ }^{\mathrm{a}}$, Amani Al-Yhmedi ${ }^{\mathrm{a}}$, Marwa Al-Shoryani $^{\mathrm{a}}$, \\ Mostafa I. Walya ${ }^{a}$ and Mohammad Shafiur Rahman ${ }^{a}$ \\ ${ }^{\text {a }}$ Department of Food Science and Nutrition, College of Agricultural and Marine Sciences, Sultan Qaboos \\ University, P. O. Box 34-123, Al-Khod, Oman \\ ${ }^{*}$ Corresponding author \\ sitharasuresh88@gmail.com \\ TEL: $+968-2414-1273$
}

Received: 5 May 2018; Published online: 18 April 2019

\begin{abstract}
In this study, the retention of vitamin $\mathrm{C}$ in fresh broccoli stored at different temperatures (i.e. chiller, room, cooking, and roasting or baking; $5-120^{\circ} \mathrm{C}$ ) was investigated. The thermal stability of vitamin $\mathrm{C}$ in broccoli was analysed at $5,20,45,60,70,80,110$, and $120^{\circ} \mathrm{C}$. The vitamin $\mathrm{C}$ content was measured by the indophenol titration method. Vitamin $\mathrm{C}$ was affected negatively at all stored temperatures. The degradation of vitamin $\mathrm{C}$ was modelled by first-order reaction kinetics and the reaction rate constants were observed as $9.03 \times 10^{-8}$ and $5.65 \times 10^{-3} \mathrm{~s}^{-1}$ when stored at $5^{\circ} \mathrm{C}$ and $120^{\circ} \mathrm{C}$, respectively. The activation energy was estimated as $74.2 \mathrm{~kJ} / \mathrm{mol}$ within the temperature range used in this study. The lowest decay of vitamin $\mathrm{C}$ was observed during the chilling condition. The data on retention of vitamin $\mathrm{C}$ in broccoli could be used to determine their stability, when stored as raw, and when heated at different temperatures.
\end{abstract}

Keywords: Ascorbic acid; First-order reaction; Cooking; Chilling; Activation energy

\section{Introduction}

Vitamins serve as an essential component in metabolism and could be used to protect the human body against diseases, such as cancer, cataracts, and cardiovascular diseases. It is shown from epidemiological studies that a high intake of vegetables and fruits is correlated with a low risk of diseases due to their antioxidants, health functional components and vitamins, such as ascorbic acid (vitamin C), carotenoids, and tocopherols (Bergquist, Gertsson, \& Olsson, 2006; Wootton-Beard \& Ryan, 2011). Broccoli has gained considerable attention due to its healthpromoting ability, which has been attributed to bioactive phytochemicals such as nitrogensulfur compounds (glucosinolates and isothio- cyanates), phenolic compounds (chlorogenic and sinapic acid derivates and flavonoids) and vitamins (Dominguez-Perles, Carmen MartinezBallesta, Carvajal, Garcia-Viguera, \& Moreno, 2010; Suresh, Al-Habsi, Guizani, \& Rahman, 2017).

Among the vitamins, vitamin $\mathrm{C}$ is one of the most important for maintaining human health (Hamad, 2009; Kumar, Ajay Kumar, Raghu, \& Manjappa, 2013). Fruits and vegetables contain a high amount of ascorbic acid. Vitamin $\mathrm{C}$ in the natural forms of L-ascorbic acid (LAA) and L-dehydroascorbic acid (L-DA) is found in foods (Ismail, 2013). It is a highly unstable molecule and could decrease during domestic and industrial processing through enzymatic and non-enzymatic reactions (Munyaka, Makule, 
Oey, Van Loey, \& Hendrickx, 2010). Therefore, processing treatments like peeling, bruising and cutting fruits or vegetables into pieces, and air exposure of the disrupted cells cause oxidation of L-AA in the presence of ascorbic acid oxidase (AAO) and this decreases the retention of ascorbic acid (Munyaka et al., 2010). The degradation can be triggered by many factors such as moisture, temperature, light, $\mathrm{pH}$, metal ions, and oxygen (Munyaka et al., 2010; Spinola, Mendes, Camara, \& Castilho, 2012). Enzymatic degradation involves oxidation of LAA to dehydroascorbic acid (L-DA) and loss of its antiscorbutic activity (i.e. ability to prevent scurvy). The antiscorbutic activity can be lost rapidly and irreversibly by hydrolysis of LDA to 2,3-diketogulonoic acid (2,3-DKG) (Jain \& Mulay, 2014). The oxidation is catalyzed by the enzymes, AAO, and ascorbic acid peroxidase (AAP) (Venkatesh \& Park, 2014).

The stability of vitamin $\mathrm{C}$ depends on many factors, such as the types of fruits and vegetables, growing conditions, level of maturity, storage and processing conditions (Masamba \& Mndalira, 2013). For instance, about 8-25\% of ascorbic acid is lost when apples are peeled. The best retention of vitamin $\mathrm{C}$ is possible with fresh or minimal processing compared with thermal and drying processing methods (Oyetade, 2012; Spinola, Mendes, Camara, \& Castilho, 2013). The ripening of fruits causes gradual loss of vitamin; however, this can be slowed down by refrigeration (Oyetade, 2012). Phillips, CouncilTroche, McGinty, Rasor, and Teresa TarragoTrani (2016) studied the stability of vitamin C in fruit and vegetable homogenates stored at different temperatures $\left(10,-20\right.$ and $\left.-55^{\circ} \mathrm{C}\right)$ and observed that the degradation depended on the storage temperatures, as well as the types of fruits and vegetables. Maximum losses were observed as $23 \%$ and $94 \%$ after 1 and 7 days of storage, respectively. The vitamin $\mathrm{C}$ stability in three types of juices (pineapple, guava and baobab) was influenced by storage temperature, storage time and types of preservatives used. At room temperature, vitamin $\mathrm{C}$ in pineapple juice $(34.7 \mathrm{mg} / 100 \mathrm{ml})$ decreased to $89.9 \%$ after 2 months of storage.

Nath, Bagchi, Misra, and Deka (2011) studied the weight loss, ascorbic acid, chlorophyll, $\beta$ - carotene, and total antioxidant activity decay in fresh broccoli stored at $15^{\circ} \mathrm{C}$ and $4{ }^{\circ} \mathrm{C}$. The ascorbic acid (i.e. $130 \mathrm{mg} / 100 \mathrm{~g} \mathrm{FW}$ ) decay of the stored samples at $15^{\circ} \mathrm{C}$ and $4^{\circ} \mathrm{C}$ (open atmosphere) were $92.9 \%$ and $29.2 \%$, respectively, after 6 days. Favell (1998) studied the stability of vitamin $\mathrm{C}$ in peas (three varieties), green beans, broccoli, and spinach at ambient, chill, and frozen conditions. They observed that the decrease of ascorbic acid in peas after postharvest varied from 26 to $31 \mathrm{mg} / 100 \mathrm{~g}$, respectively, depending on the variety. The samples stored at $4^{\circ} \mathrm{C}$ (chilled) showed little change in the first 3 days, but reduced steadily at $2-3 \%$ per day. On the other hand, the loss was much faster for the peas stored at ambient temperature $\left(20^{\circ} \mathrm{C}\right)$ and the loss was about $10 \%$ per day over the first 7 days. The ascorbic acid content of freshly harvested broccoli was reported within the $77.0-93.0 \mathrm{mg} / 100 \mathrm{~g}$ sample. A steady loss was observed for broccoli stored at ambient storage with only $44 \%$ ascorbic acid retained after 7 days of storage and $28 \%$ after 14 days. However, at chilled temperature, the retention was much better, with no loss after 7 days of storage and $80 \%$ retention even after 21 days. Most of the studies determined percent losses during a predetermined storage time. There are relatively few reports available in the literature on the degradation kinetics of vitamin $\mathrm{C}$ in fruits and vegetables (Ariahu, Abashi, \& Chinma, 2011). Yet the reaction order, rate constant, and activation energy are essential for predicting food quality loss during storage, as well as thermal processing (Nisha, Singhal, \& Pandit, 2005).

There are negligible studies in the literature on the loss of vitamin $\mathrm{C}$ in broccoli during storage and processing over a wide temperature range. The objective of this study was to determine the stability of vitamin $\mathrm{C}$ at different temperatures (i.e. $5-120^{\circ} \mathrm{C}$ ). The experiments were performed in isothermal conditions and the selected temperatures could be used to simulate the conditions of chilling and room temperature storage, cooking, and roasting or baking conditions. The reaction rate was modelled by first-order reaction kinetics. 


\section{Materials and Methods}

\subsection{Sample Collection and Preparation}

Fresh broccoli (Brassica oleracea, variety: Calabrese) grown in Oman were purchased from a local supermarket. The vegetables were washed in tap water to remove the dirt adhering to them and was spread on tissue paper to absorb the excess surface water. Only florets were cut from the bunch and eight batches of $200 \mathrm{~g}$ samples were placed into different aluminium cells and stored at temperatures of $5,20,45,60,70,80,110$, and $120^{\circ} \mathrm{C}$. Previous reports showed that depending on the type of vegetables and fruits and effects of temperature (low and high), more or less heating time would be needed to measure the vitamin C content (Hal, Bosschaart, Twisk, Verkerk, \& Dekker, 2012; El-Ishaq \& Obirinakem, 2015; Polinati, Kremer Faller, \& Fialho, 2010). Considering this aspect, different time frames were used for different storage temperatures. The heating time and temperature for broccoli samples are shown in Table 1. Samples were taken from each cell at different time intervals and their vitamin $\mathrm{C}$ content was measured.

\subsection{Measurement of Ascorbic Acid in Broccoli}

Vitamin C was measured according to the AOAC (1990) using a titration method with 2,6dichloro-indophenol reagent. Samples of $10.0 \mathrm{~g}$ broccoli were weighed at different time intervals from each storage temperature and blended with $100 \mathrm{ml}$ metaphosphoric acid (3\%). The solution was then vacuum filtered and transferred to a 100 $\mathrm{ml}$ volumetric flask. Ten $\mathrm{ml}$ of the diluted sample solution was then titrated against the standardized dye. The dye was standardized by a known concentration of ascorbic acid solution $(0.1 \mathrm{mg}$ $\mathrm{AA} / \mathrm{ml})$. The end-point was indicated by the appearance of a light pink colour. The result was expressed as mg/100 $\mathrm{g}$ fresh broccoli sample and replicated three times.

\subsection{Reaction Kinetics}

The loss or degradation of vitamin $\mathrm{C}$ is commonly modelled by the first-order reaction as follows:

$$
\operatorname{Ln}\left(\frac{C}{C_{0}}\right)=-k_{1} t
$$

where, $C$ is the concentration of vitamin $C$ in a sample at time $\mathrm{t}\left(\mathrm{mg} / \mathrm{g}\right.$ sample),$C_{0}$ is the initial concentration of vitamin $C$ in the sample $(\mathrm{mg} / \mathrm{g}$ sample), $k_{1}$ is the first-order rate constant $\left(\mathrm{s}^{-1}\right)$ and $\mathrm{t}$ is the storage time $(\mathrm{s})$.

In most of the isothermal experiments, an initial lag period was observed and the above equation was modified with an intercept rather forcing the intercept to zero as Equation 1 (Rahman et al., 2015). The experimental data was fitted with a linear equation with an intercept as follows:

$$
\operatorname{Ln}\left(\frac{C}{C_{0}}\right)=-k_{1} t+a
$$

where, a is the intercept. The rate constant was determined from the slope of a linear plot $\mathrm{Ln}$ $\left(C / C_{o}\right)$ versus $t$. Activation energy of first-order kinetics was estimated using the Arrhenius equation as:

$$
\operatorname{Ln}\left(k_{1}\right)=-\left(\frac{E_{a}}{R}\right)\left(\frac{1}{T}\right)+b
$$

where, $R$ is the universal gas constant $(8.314$ $\mathrm{J} / \mathrm{mol} \mathrm{K}), E_{a}$ is the activation energy $(\mathrm{J} / \mathrm{mol}), T$ is the temperature $(\mathrm{K})$, and $b$ is the pre-exponent factor. The activation energy was estimated from the slope of the linear plot of $L n k_{1}$ versus $1 / T$.

\subsection{Statistical Analysis}

Each experiment was replicated three times and the regression analysis of Equations 2 and 3 were performed using Microsoft Excel (MSExcel, 2016). The regression coefficient was considered as the goodness of the regression equation. 
Stability of Vitamin C in Broccoli $\mid 61$

Table 1: Temperature and heating scheme for broccoli

\begin{tabular}{lcccccccc}
\hline \multicolumn{7}{c}{ Broccoli } \\
\hline $\begin{array}{l}\text { Temperature } \\
\left({ }^{\circ} \mathbf{C}\right)\end{array}$ & $\mathbf{5}$ & $\mathbf{2 0}$ & $\mathbf{4 5}$ & $\mathbf{6 0}$ & $\mathbf{7 0}$ & $\mathbf{8 0}$ & $\mathbf{1 1 0}$ & $\mathbf{1 2 0}$ \\
$(\mathbf{D a y s})$ & $\mathbf{( h )}$ & $\mathbf{( h )}$ & $(\mathbf{m i n})$ & $(\mathbf{m i n})$ & $(\mathbf{m i n})$ & $(\mathbf{m i n})$ & $(\mathbf{m i n})$ \\
\hline Time & 0 & 0 & 0 & 0 & 0 & 0 & 0 & 0 \\
& 1 & 5 & 5.25 & 10 & 5 & 4 & 3 & 2 \\
& 3 & 19.5 & 7.25 & 27 & 15 & 9 & 6 & 5 \\
& 21 & 25.5 & 8.75 & 40 & 25 & 14 & 9 & 8 \\
& 35 & 42.5 & 10.00 & 55 & 40 & 22 & 13 & 11 \\
& 49 & & 11.25 & 70 & 50 & 32 & 19 & 16 \\
& 63 & & 12.50 & 100 & 60 & 42 & 25 & 21 \\
& 77 & & 14.50 & 115 & 70 & 52 & 31 & 26 \\
& & 15.75 & 130 & 80 & 67 & 38 & 31 \\
& & 17.00 & 145 & & 82 & 45 & 36 \\
& & 23.00 & & & 97 & & \\
& & 24.00 & & & & & \\
\hline
\end{tabular}
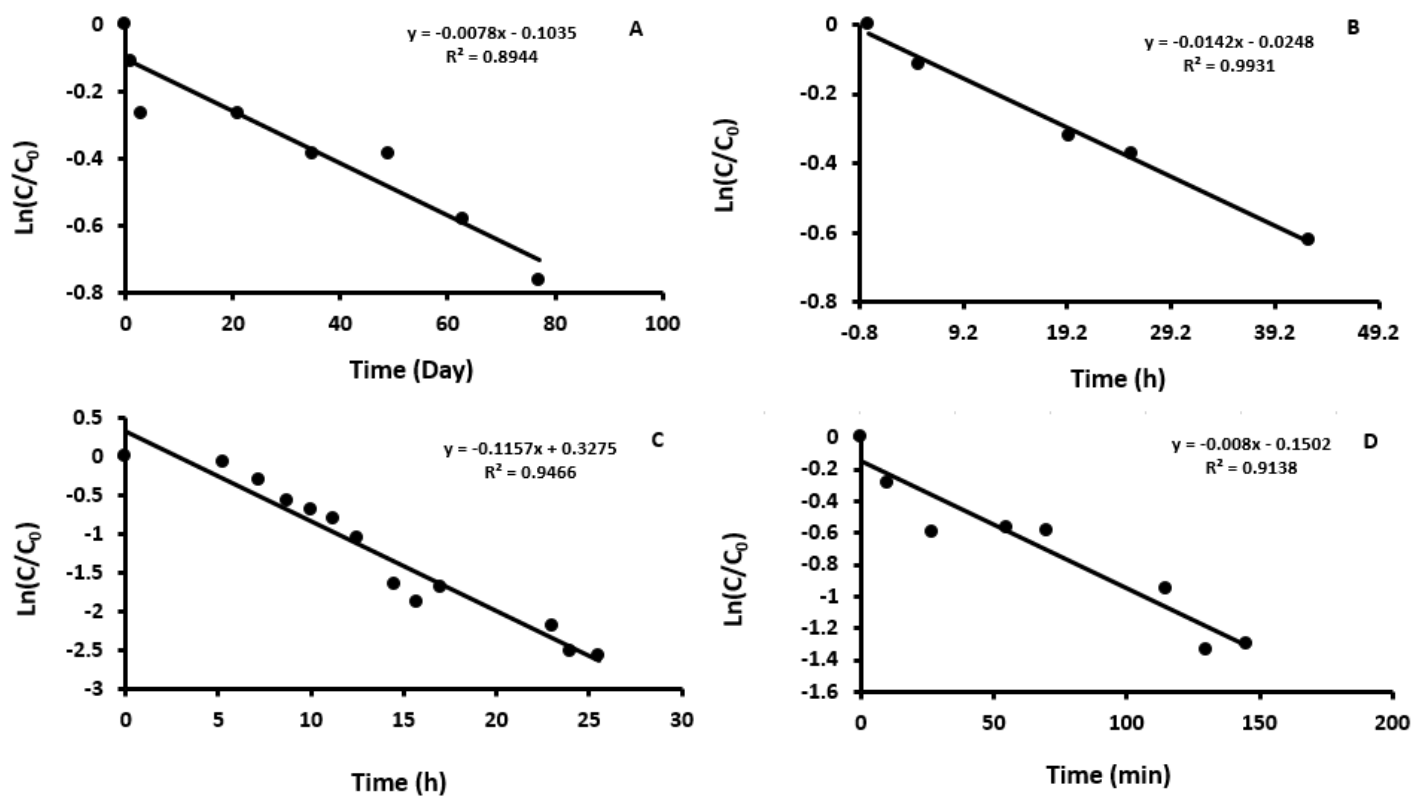

Figure 1: Plots of $\operatorname{Ln}\left(C / C_{o}\right)$ versus time. A: $5^{\circ} \mathrm{C}, \mathrm{B}: 20^{\circ} \mathrm{C}, \mathrm{C}: 45^{\circ} \mathrm{C}, \mathrm{D}: 60^{\circ} \mathrm{C}$ 
$62 \mid$ Al-Habsi et al.
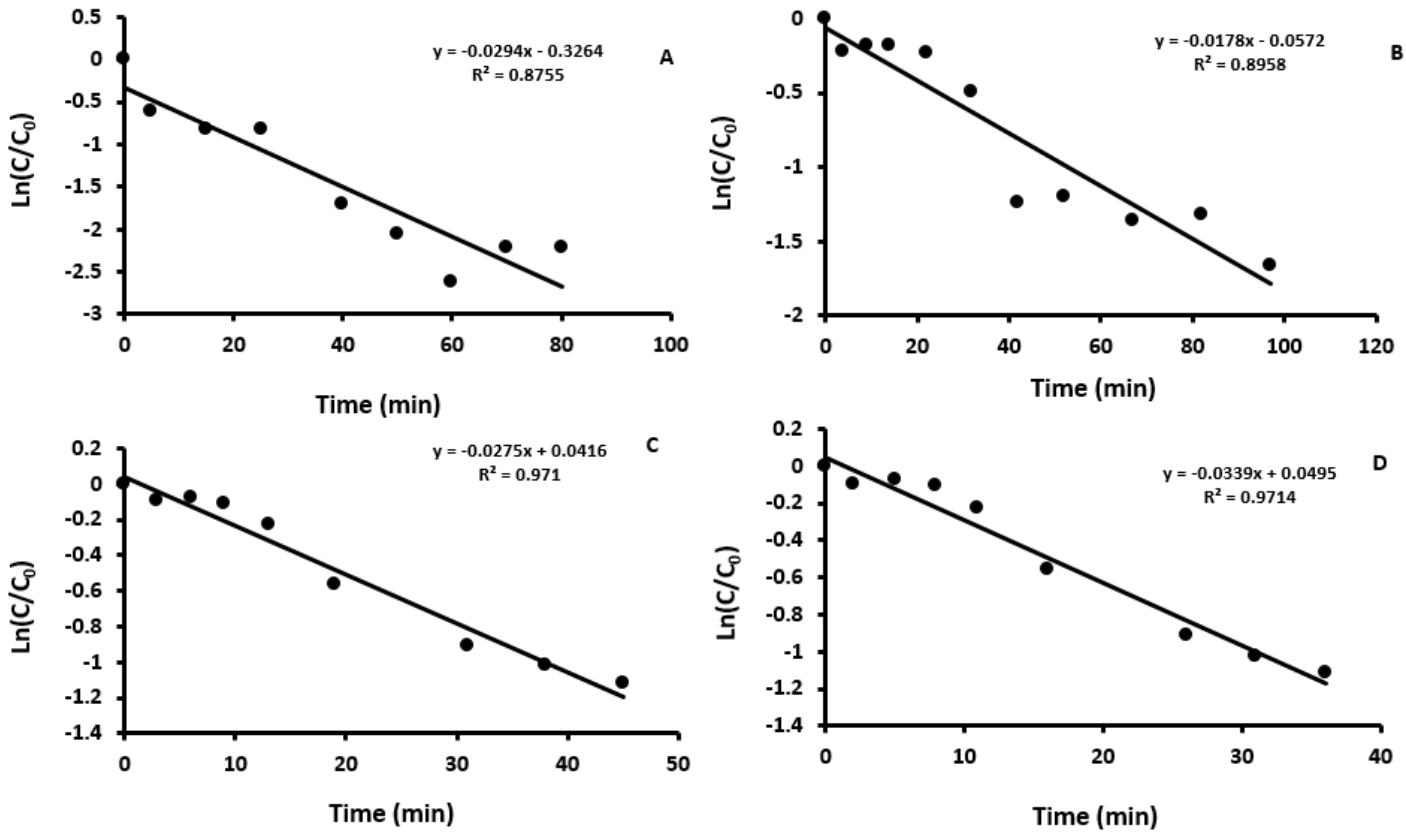

Figure 2: Plots of $\operatorname{Ln}\left(C / C_{o}\right)$ versus time. A: $70^{\circ} \mathrm{C}, \mathrm{B}: 80^{\circ} \mathrm{C}, \mathrm{C}: 110^{\circ} \mathrm{C}, \mathrm{D}: 120^{\circ} \mathrm{C}$

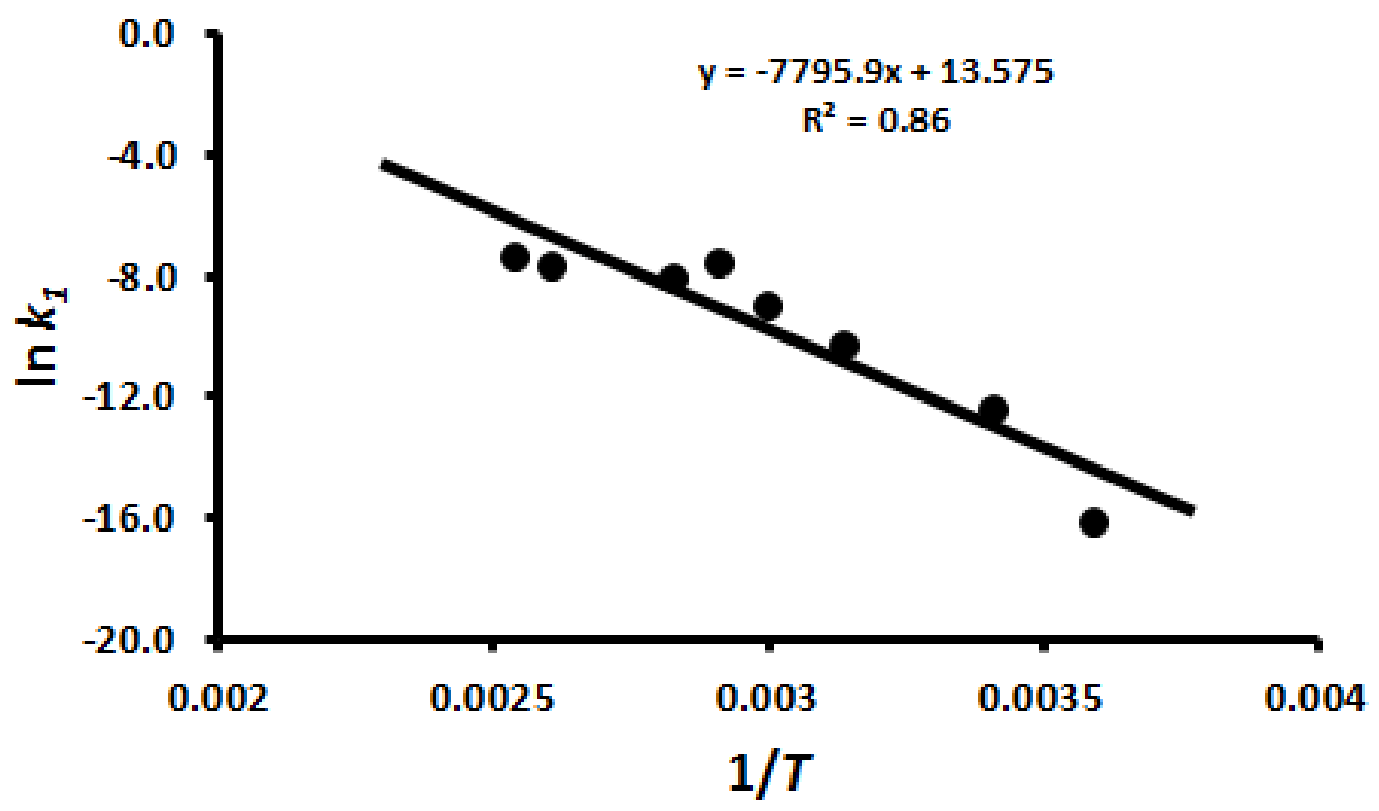

Figure 3: Arrhenius plot $\operatorname{Ln}\left(k_{1}\right)$ versus $1 / T$ 


\section{Results and Discussions}

The composition of fresh broccoli was determined and presented in our preliminary study (Suresh et al., 2017). Moisture, protein, fat, crude fibre, ash, and carbohydrate content of broccoli was $90.20,2.08,0.33,0.75,0.74$ and 5.90 $\mathrm{g} / 100 \mathrm{~g}$ sample, respectively; and $\mathrm{pH}$ was determined as 6.8. The vitamin $\mathrm{C}$ in the fresh broccoli varied from 53.6 to $64.3 \mathrm{mg} / 100 \mathrm{~g}$ sample. In order to study vitamin $\mathrm{C}$ stability with wide variations in temperature, different time frame experiments were used, as also identified earlier by Hal et al. (2012), El-Ishaq and Obirinakem (2015) and Polinati et al. (2010). The heating time frame at different temperatures is shown in Table 1. Different time frames could be used to compare vitamin $\mathrm{C}$ stability. For example, the vitamin $\mathrm{C}$ reduced to $40.4 \mathrm{mg} / 100 \mathrm{~g}$ sample (i.e. $62.8 \%$ loss) after 35 days of storage when stored in chilled conditions at $5{ }^{\circ} \mathrm{C}$, whereas vitamin $\mathrm{C}$ reduced to $45.0 \mathrm{mg} / 100 \mathrm{~g}$ sample (i.e. $69.9 \%$ loss) after $7.2 \mathrm{~h}$ when stored at $45^{\circ} \mathrm{C}$. Similarly, vitamin C reduced to 38.4 and $36.0 \mathrm{mg} / 100 \mathrm{~g}$ sample (i.e. $59.7 \%$ and $56.6 \%$ loss, respectively) after 27 and 16 min when stored at 60 and $120^{\circ} \mathrm{C}$, respectively. Therefore, time to a specific reduction of vitamin C (for example above, 36-45 mg/100 $\mathrm{g}$ sample) could be used to compare data when stored at different temperatures. However, kinetics modelling with rate constants $\left(\mathrm{s}^{-1}\right)$ better standardize the processes when different time frames are used.

The vitamin $\mathrm{C}$ (ascorbic acid, AA) losses in broccoli, cauliflower, and cabbage were studied at different stages (delivery, cooked for 30 min and blast chilled, $0-3^{\circ} \mathrm{C}$ ) (Charlton, Patrick, Dowling, \& Jensen, 2004). The AA content of broccoli, cauliflower, and cabbage from delivery to blast chilling varied from $2.9-24.0 \mathrm{mg} / 100 \mathrm{~g}$ sample. The dramatic AA losses occurred during cooking (33-81\%), with broccoli showing the great loss $(81 \%)$. During the 4-day chill storage, a steady decline of AA was observed with a loss/day of $4.2 \%$. The loss of AA levels in broccoli during chilled storage was $3.6 \%$ per day. The loss/day for cauliflower, and cabbage was $7.6 \%$ and $2.3 \%$, respectively.

Goncalves, Abreu, Brandao, and Silva (2011) studied the vitamin $\mathrm{C}$ loss in frozen broccoli
(Brassica oleracea L. ssp. Italica) during storage. The vitamin $\mathrm{C}$ content significantly decreased after 121 days of isothermal storage by $80 \%, 60 \%$, and $29 \%$, respectively at $-7,-15$, and $-25^{\circ} \mathrm{C}$. The major loss of vitamin $\mathrm{C}$ occurred during the first 55 days of storage. Shobham, Mudhavath, and Sukumaran (2017) studied the effect of microwave and pressure cooking on the stability of vitamin $\mathrm{C}$ in vegetables (carrot, potato, spinach, brinjal, cauliflower, green chilli, bitter gourd, and cabbage). The total content of vitamin $\mathrm{C}$ in raw vegetables ranged from 3.55 to $91.27 \mathrm{mg} / 100 \mathrm{~g}$. Microwave and pressure cooking for 2 to $3 \mathrm{~min}$ resulted in considerable loss of vitamin $\mathrm{C}$. The percentage loss of vitamin $\mathrm{C}$ content in cabbage subjected to microwave and pressure cooking was $9.9 \%$ and $49.5 \%$, respectively, whereas it was $20.7 \%$ for cauliflower subjected to microwave and $46.2 \%$ loss during pressure cooking. A greater loss was observed for potato and spinach. Shams El-Din, Abdel-Kader, Makhlouf, and Mohamed (2013) studied the effect of cooking methods on natural antioxidants in Brassica vegetables. The result showed that boiling had a greater loss of vitamin $\mathrm{C}$ compared to microwave cooking. Boiling for 6 min caused a loss of $64.5 \%$ in broccoli, $70.7 \%$ loss in white cabbage, and $66.8 \%$ in cauliflower.

Figures 1 and 2 show the plot of $\operatorname{Ln}\left(\mathrm{C} / \mathrm{C}_{o}\right)$ versus time according to first-order reaction kinetics (Equation 2). The high regression coefficient from 0.88 to 0.99 indicates that vitamin $\mathrm{C}$ decay can be predicted according to the first-order reaction. Similarly, first-order reaction was used for the degradation of vitamin $\mathrm{C}$ in cabbage and lettuce (Awagu, Ekanem, Kolo, \& Adamu, 2017), cherry juice (Jirasatid \& Noipant, 2015) and orange juice (Calligaris, Manzocco, \& Lagazio, 2012). The first-order reaction rate constant was determined from the slope and these increased from $9.03 \times 10^{-8} \mathrm{~s}^{-1}$ to $5.65 \times 10^{-3} \mathrm{~s}^{-1}$, when storage temperature varied from $5^{\circ} \mathrm{C}$ to $120^{\circ} \mathrm{C}$. Vitamin losses in fresh capsicum at $5^{\circ} \mathrm{C}$ and $20^{\circ} \mathrm{C}$ were observed as $8.22 \times 10^{-7}$ and $1.15 \times 10^{-6} \mathrm{~s}^{-1}$ as compared to the results found in this study of $9.03 \times 10^{-8}\left(\right.$ at $\left.5^{\circ} \mathrm{C}\right)$ and $4.03 \times 10^{-6} \mathrm{~s}^{-1}\left(\right.$ at $\left.20^{\circ} \mathrm{C}\right)$ (Rahman et al., 2015). At refrigerated temperatures, the loss of vitamin $\mathrm{C}$ in broccoli was much higher than capsicum, whereas comparable losses were observed at $20^{\circ} \mathrm{C}$. In the case of orange juice 
$64 \mid$ Al-Habsi et al.

stored at $10^{\circ} \mathrm{C}$, the rate constant was observed as $4.63 \times 10^{-7} \mathrm{~s}^{-1}$ (Calligaris et al., 2012). In the case hot water blanching of pumpkin at $\mathrm{pH} 6.5$, the rate constant increased from $8.10 \times 10^{-4}$ to $1.37 \times 10^{-3} \mathrm{~s}^{-1}$ when blanching temperature increased from $60^{\circ} \mathrm{C}$ to $90^{\circ} \mathrm{C}$ (Ariahu et al., 2011). The reaction rate constant of cherry juice increased from $3.12 \times 10-4$ to $1.00 \times 10-3 \mathrm{~s}-1$ with increasing temperatures $(75,80,85,90$ and 95 $\left.{ }^{\circ} \mathrm{C}\right)$ (Jirasatid \& Noipant, 2015). The rate constant observed in this study was similar to earlier reported values. The degradation of ascorbic acid in broccoli could be mainly due to the oxidation of ascorbic acid by oxidizing enzymes, e.g. ascorbic acid oxidase, peroxidase, catalase, and polyphenol oxidase (Mapson, 1970; Venkatesh \& Park, 2014). Two types of vitamin C degradation could occur: aerobic and anaerobic degradation. In aerobic degradation, the AA is oxidised to L-dehydro-ascorbic acid (L-DA) followed by hydrolysis and further oxidation, whereas anaerobic degradation has not been clearly studied and reported (Wang, Law, Mujumdar, \& Xiao, 2017). During processing, matrix disruption could occur thus facilitating the oxidation of L-AA to LDA by the enzyme AAO. The L-DA can then be further hydrolysed to 2,3-diketogulonic acid, thus losing its antiscorbutic activity. Other possible chemical reactions associated with changes in flavour, colour, and odour could have occurred with time due to interactions among the components and this resulted in changes in $\mathrm{pH}$ (El-Ishaq \& Obirinakem, 2015; Munyaka et al., 2010). In this study, low temperature likely caused minimal destruction of structure, thus enzymatic degradation reaction was observed at a slower rate as compared to high temperature. At high temperature, structural damage could enhance enzymatic degradation as well as increase interaction with other released components.

Figure 3 shows the Arrhenius plot of Ln $\left(k_{1}\right)$ versus $1 / \mathrm{T}$, and activation energy was estimated from the slope as $74.2 \mathrm{~kJ} / \mathrm{mol}$. Jirasatid and Noipant (2015) observed a similar activation energy of $69.4 \mathrm{~kJ} / \mathrm{mol}$ for cherry within the temperature range $75-95^{\circ} \mathrm{C}$. The higher activation energy indicated that temperature could affect degradation at a faster rate. The activation energy was observed as 58.0, 39.0, and $29.0 \mathrm{~kJ} / \mathrm{mol}$, respectively, for guava, mango, and marula pulps within the temperature range of $80-150^{\circ} \mathrm{C}$ (Hal et al., 2012). The high activation energy of vitamin $\mathrm{C}$ in broccoli implied that the deterioration was more sensitive to temperature as compared to the vitamin $\mathrm{C}$ degradation in guava, mango, and marula pulps. The activation energy of ascorbic acid loss during pumpkin blanching $\left(60-90^{\circ} \mathrm{C}\right)$ varied from 16.9 to $41.2 \mathrm{~kJ} / \mathrm{mol}$, while $\mathrm{pH}$ increased from 5.0 to 6.5 , respectively (Ariahu et al., 2011). The pH of the fresh broccoli was measured as 6.8 (Suresh et al., 2017). Therefore, the activation energy of broccoli could be expected to be higher than the reported values for pumpkin. In the case of heat treatment $\left(80-90^{\circ} \mathrm{C}\right)$ of apple, the activation energy was observed as 88.9 $\mathrm{kJ} / \mathrm{mol}$. The activation energy varied from 10.7 to 99.2 depending on the type of fruits and vegetables (Courtois, Vedrenne, \& George, 2009). Therefore, the activation energy of vitamin $\mathrm{C}$ loss depended on the types of fruits and vegetables, as well as their physicochemical properties and $\mathrm{pH}$.

\section{Conclusion}

The loss of vitamin $\mathrm{C}$ increased with storage time and temperature $\left(5-120^{\circ} \mathrm{C}\right)$. Vitamin $\mathrm{C}$ degradation in broccoli followed a first-order reaction and the temperature dependence of rate constants was described using the Arrhenius model. The activation energy was estimated as $74.2 \mathrm{~kJ} / \mathrm{mol}$. Data on the retention of vitamin $\mathrm{C}$ could be used when broccoli is stored as raw and when it is cooked at different temperatures. The rate constants at different temperatures could be used in simulation and optimization of thermal processes.

\section{Acknowledgements}

Ms. Sithara Suresh would like to appreciate Sultan Qaboos University for awarding her a Ph.D scholarship and all authors would like to acknowledge the supports of the Sultan Qaboos University (SQU) towards this research in the area of food stability. 


\section{References}

AOAC. (1990). In: Helrich K (ed) Association of official analytical chemists. Official methods of analysis of the AOAC. AOAC, Arlington.

Ariahu, C. C., Abashi, D. K., \& Chinma, C. E. (2011). Kinetics of ascorbic acid loss during hot water blanching of fluted pumpkin (telfairia occidentalis) leaves. Journal of Food Science and Technology-mysore, 48(4), 454-459. doi:10.1007/s13197-0100123-0

Awagu, E. F., Ekanem, E. O., Kolo, A. M., \& Adamu, M. M. (2017). Kinetic modeling of vitamin c (ascorbic acid) degradation in blanched commonly consumed salad vegetables using computer simulation analysis. Journal of Applied Chemistry, 10, 59-66.

Bergquist, S. A. M., Gertsson, U. E., \& Olsson, M. E. (2006). Influence of growth stage and postharvest storage on ascorbic acid and carotenoid content and visual quality of baby spinach (spinacia oleracea 1.) Journal of the Science of Food and Agriculture, 86 (3), 346-355. doi:10.1002/jsfa.2373

Calligaris, S., Manzocco, L., \& Lagazio, C. (2012). Modeling shelf life using chemical, physical, and sensory indicators. Shelf life assessment of food, 75-126.

Charlton, K., Patrick, P., Dowling, L., \& Jensen, E. (2004). Ascorbic acid losses in vegetables associated with cook-chill food preparation. South African Journal of Clinical Nutrition, 17(2), 56-63. doi:10.1080/ 16070658.2004.11734015. eprint: https:// doi.org/10.1080/16070658.2004.11734015

Courtois, F., Vedrenne, L., \& George, S. (2009). Mathematical modelling of some nutrient losses during heat treatment of stewed apples. Czech Journal of Food Sciences, 27(SI), S23-S26. 6th Chemical Reactions in Food Conferene 2009, Prague, CZECH REPUBLIC, MAY 13-15, 2009. doi:10 . 17221/966-CJFS

Dominguez-Perles, R., Carmen MartinezBallesta, M., Carvajal, M., GarciaViguera, C., \& Moreno, D. A. (2010). Broccoli-derived by-products-a promising source of bioactive ingredients. Journal of Food Science, 75(4), C383-C392. doi:10.1111/j.1750-3841.2010.01606.x

Favell, D. J. (1998). A comparison of the vitamin c content of fresh and frozen vegetables. Food Chemistry, 62(1), 59-64. doi:10. 1016/S0308-8146(97)00165-9

Goncalves, E. M., Abreu, M., Brandao, T. R. S., \& Silva, C. L. M. (2011). Degradation kinetics of colour, vitamin $\mathrm{c}$ and drip loss in frozen broccoli (brassica oleracea l. ssp italica) during storage at isothermal and non-isothermal conditions. International Journal of Refrigerationrevue Internationale Du Froid, 34(8), 2136-2144. 23rd International-Institute-ofRefrigeration(IIR) International Congress of Refrigeration, Prague, CZECH REPUBLIC, AUG 21-26, 2011. doi:10.1016/j . ijrefrig.2011.06.006

Hal, P. H., Bosschaart, C., Twisk, C. V., Verkerk, R., \& Dekker, M. (2012). Kinetics of thermal degradation of vitamin $\mathrm{c}$ in marula fruit (sclerocarya birrea subsp caffra) as compared to other selected tropical fruits. LWT-Food Science and Technology, 49(2, SI), 188-191. doi:10.1016/j.lwt.2011.12.038

Hamad, Q. Y. M. M. (2009). Spectrophotometric determination of total vitamin $\mathrm{c}$ in some fruits and vegetables at koya areakurdistan region/iraq. Kirkuk University Journal for Scientific Studies, 4(2), 46-54.

El-Ishaq, A., \& Obirinakem, S. (2015). Effect of temperature and storage on vitamin c content in fruits juice. 1, 17-21.

Ismail, F. (2013). Determination of water soluble vitamin in fruits and vegetables marketed in sindh pakistan.

Jain, H., \& Mulay, S. (2014). A review on biological functions and sources of anti- scorbutic factor: Vitamin c.

Jirasatid, S., \& Noipant, P. (2015). Thermal degradation kinetics of vitamin $\mathrm{c}$ in jamaican cherry (muntingia calabura 1.) juice. In Burapha University International Conference, 10-12 July, Bangsaen, Chonburi, Thailand. Retrieved from http: / / www . buuconference . buu . ac . th / registration / getdownload . php ? name = paper116 \& file $=$ file $/$ BUU2015 / paper116 . pdf 
Kumar, G. V., Ajay Kumar, K., Raghu, P. G. R., \& Manjappa, S. (2013). Determination of vitamin $\mathrm{c}$ in some fruits and vegetables in davanagere city,(karanataka)-india. International Journal of Pharmacy \& Life Sciences, $4(3)$.

Mapson, L. W. (1970). Vitamin in fruits. The biochemistry of fruits and their products, 1 , 369-386.

Masamba, K. G., \& Mndalira, K. (2013). Vitamin c stability in pineapple, guava and baobab juices under different storage conditions using different levels of sodium benzoate and metabisulphite. African Journal of Biotechnology, 12(2), 186-191.

Munyaka, A. W., Makule, E. E., Oey, I., Van Loey, A., \& Hendrickx, M. (2010). Thermal stability of l-ascorbic acid and ascorbic acid oxidase in broccoli (brassica oleracea var. italica). Journal of Food Science, 75 (4), C336-C340. doi:10.1111/j.17503841.2010.01573.x

Nath, A., Bagchi, B., Misra, L. K., \& Deka, B. C. (2011). Changes in post-harvest phytochemical qualities of broccoli florets during ambient and refrigerated storage. Food Chemistry, 127(4), 1510-1514.

Nisha, P., Singhal, R. S., \& Pandit, A. B. (2005). A study on degradation kinetics of riboflavin in green gram whole (vigna radiata 1.) Food Chemistry, 89(4), 577-582. doi:10.1016/j.foodchem.2004.03.014

Oyetade, O. A. (2012). Stability studies on ascorbic acid (vitamin c) from different sources. 2, 20-24.

Phillips, K. M., Council-Troche, M., McGinty, R. C., Rasor, A. S., \& Teresa TarragoTrani, M. (2016). Stability of vitamin c in fruit and vegetable homogenates stored at different temperatures. Journal of Food Composition and Analysis, 45, 147-162. doi:10.1016/j.jfca.2015.09.008

Polinati, R. M., Kremer Faller, A. L., \& Fialho, E. (2010). The effect of freezing at-18 degrees $\mathrm{c}$ and-70 degrees $\mathrm{c}$ with and without ascorbic acid on the stability of antioxidant in extracts of apple and orange fruits. International Journal of Food Science and Technology, 45(9), 1814-1820. doi:10.1111/ j.1365-2621.2010.02333.x
Rahman, M. S., Al-Rizeiqi, M. H., Guizani, N., Al-Ruzaiqi, M. S., Al-Aamri, A. H., \& Zainab, S. (2015). Stability of vitamin $c$ in fresh and freeze-dried capsicum stored at different temperatures. Journal of Food Science and Technology-mysore, 52(3), 1691-1697. doi:10.1007/s13197-0131173-x

Shams El-Din, M. H. A., Abdel-Kader, M. M., Makhlouf, S. K., \& Mohamed, O. S. S. (2013). Effect of some cooking methods on natural antioxidants and their activities in some brassica vegetables. 26, 697-703.

Shobham, K. R., Mudhavath, M., \& Sukumaran, M. K. (2017). Effect of Microwave and Pressure Cooking on Stability of Vitamin $\mathrm{C}$ in Some Selected Vegetables. International Journal of Current Microbiology and Applied Sciences, 6(9), 2391-2397. doi:10. 20546/ijcmas.2017.609.293

Spinola, V., Mendes, B., Camara, J. S., \& Castilho, P. C. (2012). An improved and fast uhplc-pda methodology for determination of l-ascorbic and dehydroascorbic acids in fruits and vegetables. evaluation of degradation rate during storage. Analytical and Bioanalytical Chemistry, 403(4), 1049-1058. doi:10.1007/s00216-011-5668-x

Spinola, V., Mendes, B., Camara, J. S., \& Castilho, P. C. (2013). Effect of time and temperature on vitamin c stability in horticultural extracts. uhplc-pda vs iodometric titration as analytical methods. $L W T$ Food Science and Technology, 50(2), 489495. doi:10.1016/j.lwt.2012.08.020

Suresh, S., Al-Habsi, N., Guizani, N., \& Rahman, M. S. (2017). Thermal characteristics and state diagram of freeze-dried broccoli: Freezing curve, maximal-freezeconcentration condition, glass line and solids-melting. Thermochimica Acta, 655, 129-136. doi:10.1016/j.tca.2017.06.015

Venkatesh, J., \& Park, S. W. (2014). Role of lascorbate in alleviating abiotic stresses in crop plants. Botanical Studies, 55. doi:10. 1186/1999-3110-55-38

Wang, J., Law, C., Mujumdar, A., \& Xiao, H.-W. (2017). The degradation mechanism and kinetics of vitamin $\mathrm{c}$ in fruits and vegetables during thermal processing. 
Stability of Vitamin C in Broccoli $\mid 67$

Wootton-Beard, P. C., \& Ryan, L. (2011).

Improving public health?: The role of antioxidant-rich fruit and vegetable beverages. Food Research International, $44(10)$, 3135-3148. doi:10.1016/j.foodres.2011.09.

015 